\title{
Future change of temperature and precipitation extremes in South America as derived from the PRECIS regional climate modeling system
}

\author{
J. A. Marengo, ${ }^{\text {a }}$ R. Jones, ${ }^{\mathrm{b}}$ L. M. Alves ${ }^{\mathrm{a}}$ and M. C. Valverde ${ }^{\mathrm{a}}$ \\ ${ }^{a}$ CPTEC/INPE, Rodovia Dutra Km, 40 12630-000 Cachoeira Paulista, São Paulo, Brazil \\ ${ }^{\mathrm{b}}$ UK Met Office Hadley Centre (Reading Unit), Meteorology Building, University of Reading, Reading, RG6 6BB, UK
}

\begin{abstract}
Using the PRECIS regional climate modeling system this study analyses the distribution of extremes of temperature and precipitation in South America in the recent past (1961-1990) and in a future (2071-2100) climate under the IPCC SRES A2 and B2 emissions scenarios. The results show that for the present climate the model simulates well the spatial distribution of extreme temperature and rainfall events when compared with observations, with temperature the more realistic. The observations over the region are far from comprehensive which compromises the assessment of model quality. In all the future climate scenarios considered all parts of the region would experience significant and often different changes in rainfall and temperature extremes. In the future, the occurrence of warm nights is projected to be more frequent in the entire tropical South America while the occurrence of cold night events is likely to decrease. Significant changes in rainfall extremes and dry spells are also projected. These include increased intensity of extreme precipitation events over most of Southeastern South America and western Amazonia consistent with projected increasing trends in total rainfall in these regions. In Northeast Brazil and eastern Amazonia smaller or no changes are seen in projected rainfall intensity though significant changes are seen in the frequency of consecutive dry days. Copyright (c) 2009 Royal Meteorological Society
\end{abstract}

KEY WORDS downscaling; climate change; vulnerability

Received 3 August 2007; Revised 5 January 2009; Accepted 11 January 2009

\section{Introduction}

Large departures from a mean climate state (hereafter 'extreme events') occur on scales ranging from days to millennia though in this paper we will focus short-term extreme (weather related) events given their potential for significant impacts. Extreme climate events are also an integral aspect of climate variability, i.e. defining its envelope as well as being important contributors to the mean and other measures such as its standard deviation. This explains the difficultly in viewing short-term extreme events as a manifestation of either 'weather' or 'climate'. From a climatological point of view, short-term extremes are events whose probability of occurrence is conditioned by larger scale, longer lasting patterns which dynamically favour or inhibit the short-term events.

One of the most important questions regarding shortterm extreme events is whether their occurrence is increasing or decreasing over time; i.e. whether the shape of the distribution, which defines if these events occur more or less frequently, is changing significantly. Statistically this can be thought of as resulting from changes of the variable's mean and/or other parameters of

* Correspondence to: J. A. Marengo, CPTEC/INPE, Rodovia Dutra Km, 40 12630-000 Cachoeira Paulista, São Paulo, Brazil.

E-mail: marengo@cptec.inpe.br its distribution or climatologically as a result of changes in the frequency and intensity of the associated weather events themselves and/or the occurrence of the large-scale patterns conditioning these events. Thus a sequential analysis of time series can determine the existence of trends without giving any information on the underlying causes (even in the absence of abrupt changes which may have contributed).

Cold spells, heat and cold waves, intense rainfall, floods, dry spells among other extreme events affect South America in all seasons, and their impacts vary according to the sector. Heavy or extreme precipitation events have important effects on society, since flash floods associated with intense, but often brief, rainfall events may be the most destructive of extreme events. Over many areas the frequency of heavy precipitation events has increased, consistent with warming, and widespread changes in extreme temperatures have been observed over the last 50 years (Intergovernmental Panel on Climate Change IPCC, 2007a; Marengo et al., 2007). Cold days, cold nights and frost have become less frequent; while hot days, hot nights, and heat waves have become more frequent (Vincent et al., 2005; Alexander et al., 2006; Caesar et al., 2006; Haylock et al., 2006; Tebaldi et al., 2006). Such changes in extremes have impacts on human activities such as agriculture, 
human health, urban development and planning and water resources management.

Climate scenarios rely upon the use of numerical models. The continuous evolution of these models over recent decades has been driven by a considerable increase in computational capacity, with supercomputer speeds increasing by roughly a factor of a million in the three decades from the 1970s to the present day. This computational progress has permitted a corresponding increase in model complexity (by including more and more components and processes), in the length of the simulations and in spatial resolution. The models used to evaluate future climate changes have therefore evolved over time. Global models have allowed for a better scientific understanding of anthropogenic global climate change and this led to commensurate developments of mitigation strategies. However, at the regional scale there remains an urgent need for relevant, targeted projections of regional climate change. Furthermore, adaptation, as opposed to mitigation, is inherently a local and regional scale issue, and limited by the measure of confidence in the projected changes at these scales.

Therefore, it is at regional scales that credible information of probable climate change is most urgently needed to facilitate the development of appropriate adaptation strategies. Without appropriate regional projections of climate change, it is arguable whether regional adaptation strategies can be developed or implemented, other than on a 'no regrets, best practice' basis (Intergovernmental Panel on Climate Change IPCC, 2007a, 2007b). On the other hand, regional adaptation strategies can also be developed without regional projections (Dessai et al., 2005). The top-down approach adopted on this paper is just one strategy; while others advocate vulnerability assessment as the basis for adaptation (Washington et al., 2006). In fact, the latter may be more appropriate for adaptation decisions in the nearer-term (such as for the 2010-2030 time slice) where the impact of climate variability will often outweigh the incremental effect of climate change (Christensen et al., 2007a, Table 11.1). The applicability and usefulness of PRECIS scenarios presented here is more for a later time slice (2071-2100), and constitutes a limitation of this study since we cannot provide discussions of climate risk information for near-term time horizons.

Within the impacts and adaptation community (e.g. agriculture, water resources management, health, among others) there is a growing move towards integrated assessment, wherein regional climate change projections form a principal factor for decision support systems aimed at reducing vulnerability. At present the regional projections are perhaps the weakest link in this process and the bulk of information readily available for policy and resource managers is largely derived from Global Climate Models (GCMs). Due to their coarse resolution, these models have limited skill in accurately simulating local scale climates especially the key variable of precipitation. GCM data are commonly mapped as continuous fields, and with different model skill and climate predictability. This may result in climate forecasts (at seasonal level) and in climate change projections which have little value for local application in impacts and vulnerability studies.

In view of the pressing need for regional projections, much effort has been expended in recent years on developing regional projections through diverse methodologies (Wilby and Wigley, 1997), and significant advances made to downscale the GCM skilful scale to the regional and local scales, either through high resolution dynamical modeling, or via empirical cross-scale functions. However, to date, much of the work remains at the level of methodological development. Climate change projections that are tailored to the needs of the impacts community, and which demonstrate convergence of the projections across different forcing GCMs, are only now beginning to become more available.

In this study we focus on the application of the Regional Climate Models (RCM), the main dynamical downscaling technique. RCMs represent an effective method of adding fine-scale detail to simulated patterns of climate variability and change as they resolve better the local land-surface properties such as orography, coasts and vegetation and the internal regional climate variability through their better resolution of atmospheric dynamics and processes (Jones et al., 1995). Dynamical downscaling in South America has been developed for better understanding of the physical processes in the atmosphere, as well as in weather and climate forecasting (Seluchi and Chou, 2001; Chou et al., 2002; Nicolini et al., 2002; Misra et al., 2003; Seth and Rojas, 2003; Chou et al., 2004). The 'added value' provided by the regionalization techniques depend on the spatial and temporal scales of interest, as well as on the variables concerned and on the climate statistics required. A review of the different downscaling methods can be found in Wilby and Wigley (1997), and Giorgi et al. (2004), as well as in the IPCC Third Assessment Report (Giorgi et al., 2001; Mearns et al., 2001), and the IPCC Fourth Assessment Report (Christensen et al., 2007b).

Despite the concerns raised above about their resolution, initial analysis of the effect of climate change in extremes has been carried out using GCMs (e.g. Kiktev et al., 2003; Hegerl et al., 2004). Tebaldi et al. (2006) have documented changes in extremes worldwide using an ensemble of 16 GCMs assessed in the IPCC AR4 under the A1B SRES scenario for 2080-2099. In South America the projections show tendencies for increasing extremes in temperatures in the entire continent, while rainfall extremes show more regional variability, with increase in the frequency and intensity of extremes on subtropical South America and negative trends in some sections of tropical and subtropical South America. Observations show a tendency for increase in the frequency of extreme rainfall events in Northeast Brazil, southern and southeastern Brazil (Groissman et al., 2005; Alexander et al., 2006; Marengo et al., 2007). 
Analysis of models from the Coupled Model Intercomparison Project (CMIP3) which contributed to the assessment of future climate change scenarios in South America in the IPCC AR4 (Li et al. 2006; Vera et al., 2006; Meehl et al., 2007; Christensen et al., 2007b) has shown that there is considerable dispersion among models regarding the ENSO amplitude and the Southern Hemisphere circulation response to ENSO in the twentieth century. However, the models are able to reproduce the main features of the precipitation seasonal cycle over South America. There is a general consensus among models in the projected precipitation changes of: (1) an increase of summer precipitation over southeastern subtropical South America; (2) a reduction of winter precipitation over most of the continent; and (3) reduction of precipitation in all seasons along the southern Andes. Li et al. (2006) show that the CMIP3 GCMs project very different changes of rainfall over the Amazon under the A1B scenario for global climate change. Five of the eleven models project an increase of annual rainfall, three models project a decrease of rainfall, and the other three models project no significant changes in the Amazon rainfall.

The issue of the spatial resolution in scenarios must be put in the context of other uncertainties of climate change. Studies and analyses of climate change impact and adaptation assessments recognize that there are a number of sources of uncertainty in such studies which contribute to uncertainty in the final assessment. The importance of high resolution climate scenarios for impacts and adaptation studies remains to be thoroughly explored in South America. High resolution scenarios developed from regional climate model results have been obtained in various parts of the world: China (Zhang et al., 2006), Pakistan (Islam and Rehman, 2007), Europe (Christensen and Christensen, 2003; Frei et al., 2006) and in South America (Marengo and Ambrizzi, 2006; Nuñez et al., 2006; Marengo et al., 2007; Solman et al., 2008; Soares and Marengo, 2008).

In Europe several national and international projects have used RCMs to help quantify better regional climate change and provide regional climate scenarios for assessing climate change impacts and vulnerability. These include the UK Climate Impacts Programme (Hulme et al., 2002), the European Projects PRUDENCE (Giorgi et al., 2004; Gao et al., 2006; Christensen et al., 2007b) and STARDEX (Haylock et al., 2006). These have all followed a standard experimental design of using one or two GCMs to drive various regional models from meteorological services and research institutions in the regions to provide dynamically downscaled regional climate projections. Typically, a present day (e.g. 1961-1990) and a future climate $(2070-2100)$ time slices are simulated to calculate changes in relevant climatic variables with interpolation techniques (e.g. Morales et al., 2007) used to derive information for nearer time periods.

Recognizing that multiple GCMs are required to provide comprehensive regional climate scenarios, current projects in Europe (ENSEMBLES, Hewitt and Griggs, 2004) and North America (NARCCAP, Mearns, 2004) are downscaling several GCMs to provide high resolution climate change scenarios for each region, though still only sampling a limited uncertainty range. These are the most advanced regional programmes delivering detailed climate scenarios and whilst the output is not comprehensive it is still having a significant impact in raising awareness of the potential seriousness of climate change and providing plausible high resolution future climates being used in impacts models helping to lay the methodological basis for future adaptation studies.

A similar initiative has been recently implemented in South America, CREAS (Regional Climate Change Scenarios for South America - Marengo and Ambrizzi, 2006; Marengo et al., 2007). It aims to provide high resolution climate change scenarios in South America for raising awareness among government and policy makers in assessing climate change impact, vulnerability and in designing adaptation measures. CREAS runs three regional models nested in HadAM3P (a GCM used in PRUDENCE): Eta for Climate Change Studies - Eta CCS - (Pisnitchenko and Tarasova, 2007), RegCM3 (Ambrizzi et al., 2007) and HadRM3P (Jones et al., 2004; Marengo and Ambrizzi, 2006). CREAS will explore issues such as: the challenge of using regional climate projections to develop plausible scenarios for future changes at daily time scales for extreme events; an assessment of current methods of scenario development for regions where data is available; assessments of vulnerability in regions and key sectors in South America.

The focus of this study is HadRM3P, the RCM within PRECIS which has been used to develop regional climate change scenarios worldwide (e.g. Tadross et al., 2005; Rupa Kumar et al., 2006; Xu et al., 2006a,b; Islam and Rehman, 2007) including studying extremes (Zhang et al., 2006). In this paper we assess the performance of HadRM3P in simulating present extreme climate events by comparing simulated trends over the period 1961-1990 with those observed. HadRM3P projected changes in extremes under the two climate change scenarios. HadRM3P simulations of indices of climate extremes of the period 2071-2100 under the IPCC SRES (Special Report on Emissions Scenarios, Nakicenovic et al., 2000) A2-high emission and B2-low emission scenarios are then compared with the 1961-1990 simulation to assess how extremes will changes under these two climate change scenarios. The HadRM3P simulations have been driven with boundary conditions from HadAM3P (the GCM on which the CREAS simulations are based) and are run at $50 \mathrm{~km}$ resolution. We also make a preliminary qualitative assessment of possible impacts and vulnerability of some key sectors in South America (water resources, biodiversity, and human health) due to changes in climate extremes.

\section{Methodology}

PRECIS (Providing Regional Climates for Impacts Studies) is a regional climate modeling system developed by 
the Hadley Centre allowing the RCM it incorporates, HadRM3P, to be run over any area of the globe (see Jones et al. 2004 which also includes a detailed description of HadRM3P). HadRM3P has 19 vertical levels and a choice of two horizontal resolutions, $50 \mathrm{~km}$ as used in this study (and the standard resolution for larger areas) and $25 \mathrm{~km}$ for smaller areas and when higher resolution is particularly important. Lateral boundary conditions for HadRM3P are available from a range of model and observationally based sources and in this study are obtained from the global atmospheric GCM, HadAM3P. The horizontal resolution of HadAM3P is $1.25^{\circ}$ latitude by $1.875^{\circ}$ longitude and the model formulation is the same as HadRM3P, an experimental setup which promotes consistency of the high resolution climate change projections from the RCM with those from the global model.

The experimental design of the driving HadAM3P experiment is described by Rowell (2005) and is summarised as follows. The HadAM3P 1961-1990 simulation is forced by observed sea-surface temperatures and sea-ice (SSTs) from the HadISST1 dataset. For the future period, 2071-2100, HadAM3P is forced by SSTs which are formed from observed SSTs with the addition of mean changes and trends calculated a global coupled model projection. The coupled integration was performed with HadCM3 (Gordon et al., 2000) whose atmospheric component, HadAM3 (Pope et al., 1999), is the basis for HadAM3P (Jones et al., 2008). The same SSTs were used as the lower boundary condition for the HadRM3P simulations. Matching the SST forcing, the HadAM3P and HadRM3P simulations for the period 1961-1990 (present climate) incorporated observed GHG concentrations and $\mathrm{SO}_{2}$ emissions and for the period 2071-2100 incorporated GHG concentrations and $\mathrm{SO}_{2}$ emissions taken from the SRES A2 and B2 emissions scenarios.

Before analyzing trends in extremes we include a short section on the validation of rainfall and temperature for the present climate. To simulate the climate of 1961-1990, HadRM3P was integrated for 31 years (1960-1990) using distinct initial and boundary conditions from three HadAM3P integrations. The first year of simulations were neglected in order to avoid spin-up problems. Three AGCM integrations (each started from different initial conditions but using the same observed timeseries of SSTs) were used to better sample the climatology of the model, averaging or pooling results from these simulations reduces the impact of simulated internal atmospheric variability on the representativeness of climatological features derived from them (Kendon et al., 2008). Thus the model's seasonal and annual climatology for the present day are obtained from an ensemble of three 30 years of simulations. The model simulations of precipitation and surface air temperature are compared with the observational dataset compiled by the Climatic Research Unit - CRU (New et al., 2001). Biases are estimated at seasonal time scale, and anomaly correlations are calculated to assess the model skill.
Having investigated the quality of the mean climatology of HadRM3P we then investigate its ability to simulate observed trends in extremes of the surface climate. With the experimental design we have chosen of using models driven by observed time series of SSTs, atmospheric greenhouse gases and sulphur emissions, if the models are responding correctly to these forcings then they should reproduce observed trends. This follows from the main factor involved in the decadal-scale natural variability of the atmospheric component of the climate system being variations in sea-surface temperature (Rowell and Zwiers, 1999) and that the main external drivers of observed climatological trends are greenhouse gases and sulphate aerosols (Intergovernmental Panel on Climate Change IPCC, 2007a). Clearly in regions where seasonal climate predictions have skill in simulating rainfall under the influence of SST anomalies, as in Amazonia, Northeast Brazil and southern Brazil-La Plata basin (Marengo et al., 2003), trends in SSTs alone may well be expected to lead to trends in extremes.

The validation of the simulated extremes for the present (1961-1990) was done using temperature and precipitation records of 104 stations in South America, mostly concentrated in South America of $6^{\circ} \mathrm{S}$. 30-year trends have been computed at each station following Alexander et al. (2006). This density of stations is clearly completely inadequate to gain a truly regional picture of changing extremes and thus will provide for only a limited portrayal of observed changes and the model's ability to capture these. Thus it is obvious that we need to fill the remaining data gaps especially over the regions of northern and tropical South America.

The indices used to calculate short-term extreme climate events were defined by Frich et al. (2002). These indices sample the tail of a reference period distribution and have been calculated for 1961-1990 present and 2071-2100 future, for both scenarios A2 and B2.

From a total of 27 indices we calculated:

Very cold nights (TN10): The percentage of time in a year when daily minimum temperature is below the 10th percentile of the 1961-1990 daily temperature distribution,

Very warm nights (TN90): The percentage of time in a year when daily minimum temperature is above the 90th percentile of the 1961-1990 daily temperature distribution.

Consecutive dry days (CDD): The annual maximum number of consecutive days when daily precipitation was less than $1 \mathrm{~mm}$

Maximum 5-day precipitation (R5 $\times$ Day): The annual maximum consecutive 5-day precipitation total that could led to flooding

Extreme rainfall (R95P): The annual total PRCP when precipitation is above the 95th percentile of the 19611990 daily precipitation distribution

Wet days (R10): The number of days in a year with precipitation above $10 \mathrm{~mm}$ 
These indices do not represent extremely rare events, for which the computation of significant trends could be a priori hampered by the small sample sizes. The trend is assumed as linear and represents the values of 1990 minus 1961. Trends have been estimated by fitting a straight line to the data. The statistical significance of such a trend is determined by conducting a Student's ttest. This approach has been used because of its simplicity and it produces similar results to trends derived by using a least square fit.

\section{Validation of precipitation and temperature for present climate}

Before analyzing the extremes in present climate, from both model and observations, we discuss the climatological features of the present climate in South America derived from HadRM3P nested in HadAM3P for 1961-1990 (Alves, 2007). The regional model reproduces realistically the spatial and temporal patterns of precipitation and temperature in tropical and subtropical South America (Figures 1 and 2, respectively). Some systematic biases in precipitation are detected during the warm rainy season in tropical South America (DJF and MAM), and in northern Amazonia-southern Venezuela during the warm season JJA. Similar biases were detected in various AGCMs, such as the NASA GISS and the CPTEC/COLA, where systematic underestimation has been precipitation in Amazonia and parts of west central Brazil, as well as overestimation is detected near the Andes. Marengo et al. (2003) have suggested that the parameterization of radiation or land-surface processes may be associated with these underestimation, and a possible effect of local dynamic forcings such as dry or wet soil may be dominant over the large-scale SST forcing, and is better detected in the anomaly correlation fields.

While the model reproduced well the temperature field on the equatorial zone, there is a systematic cold bias throughout the year compared to the CRU temperature climatology. Though systematic, the bias is not large and could be due to the fact that the CRU data set includes fewer stations that report air temperature in tropical South America. The model skill for seasonal temperature variability is relatively lower in regions of southeastern and west central Brazil, as compared to Amazonia, Northeast Brazil or the La Plata basin. This indicates regions where seasonal variability is determined less by SSTs and more by internal atmospheric variability. The seasonal cycle of precipitation and temperature and the location of the peak season, as well as the main largescale circulation patterns are well reproduced in South America, with the above indicated positive or negative biases (Alves, 2007).

Clearly in any regions identified here where there are significant biases the model would probably be expected to not simulate well the magnitude of any trend. In many regions the biases are relatively low and the patterns and seasonal cycle of the climatological features are well simulated implying that it is reasonable to analyse at least the sign and possibly the magnitude of simulated trends in the model.

\section{Validation of trends extreme climate indices for present climate}

The observed and simulated spatial distribution of trends for the six extremes indices are shown in Figure 3 $(a-f)$ and $(g-1)$, respectively. Generally, the temperaturebased indicators have trends which are consistent with the observed average regional warming. The observed TN10 (cold nights) and TN90 (warm nights) indices suggest, respectively, negative and positive trends. There are two exceptions which appear to have some regional consistency and are increasing trends in cold nights in northern Peru and Ecuador and in Paraguay. Observations show positive trends in all three indices of extreme rainfall in southeastern South America and the western coast of Peru and Ecuador, while southern Chile shows negative trends. The maximum consecutive dry day length shows a negative trend in southern stations and in South East Brazil and generally strong positive trends elsewhere.

The HadRM3P simulated trends are displayed in Figure $3(\mathrm{~g}-1)$. They match well the patterns of negative trends in the cold nights in Southeastern South America, while the simulations for the warm night indices show the positive trends though the model underestimates these. In regions with no observational coverage the HadRM3P simulations show also negative cold night trends and positive warm night trends, both in Northeast Brazil and in the Amazon Basin. The observed positive trends in TN10P noted above are not captured by the model and this coincides with regions of large observed increases in consecutive dry days also not simulated. Significant increases in dry days would imply significant reductions in cloudy days which could be responsible for the increases in cold nights though more detailed analysis would be required to confirm this.

The positive trends in TN90 simulated over Venezuela by the model are consistent with the positive trends observed by Alexander et al. (2006) and Caesar et al. (2006). The changes in temperature indices reflect an increasing trend in both maximum and minimum temperatures, which are consistent with the results of Marengo and Camargo (2007) for southern Brazil and Rusticucci and Barrucand (2004) in northern Argentina.

The broad spatial pattern of observed trends in R10mm is well simulated by the model, with positive trends in large regions of Southeastern South America and negative trends around $40^{\circ} \mathrm{S}$ in Chile. The simulated trends in western Amazonia are consistent with those observed in stations in that region. The trends of $\mathrm{R} \times 5$ day and $\mathrm{R} 95 \mathrm{P}$ are consistent between observations and simulations in northern Argentina, Uruguay and parts of Paraguay where they are generally increasing. In southern Brazil these indices have positive trends in the model simulations which is consistent with the few stations of $20^{\circ} \mathrm{S}$ but 

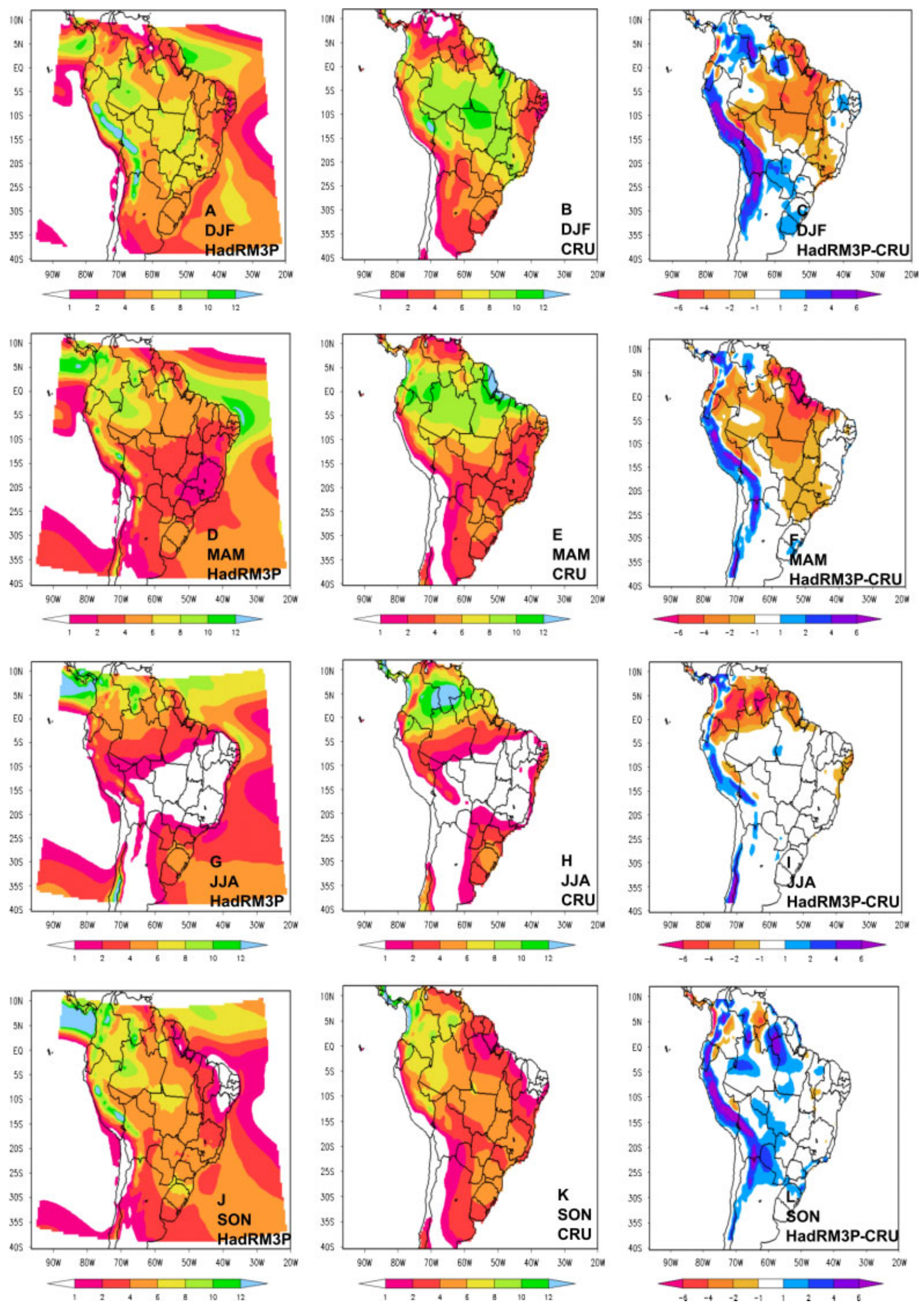

Figure 1. Present climate seasonal precipitation ( $\mathrm{mm} /$ day) simulated by the HadRM3P regional model (left), and from observations (CRU-center) $(\mathrm{a}-\mathrm{c})$ Summer (DJF); (d-f) Autumn (MAM); ( $-\mathrm{i})$ Winter (JJA); (j-l) Spring (SON). Bias (difference between model and observations) is shown to the extreme right. This figure is available in colour online at www.interscience.wiley.com/ijoc 

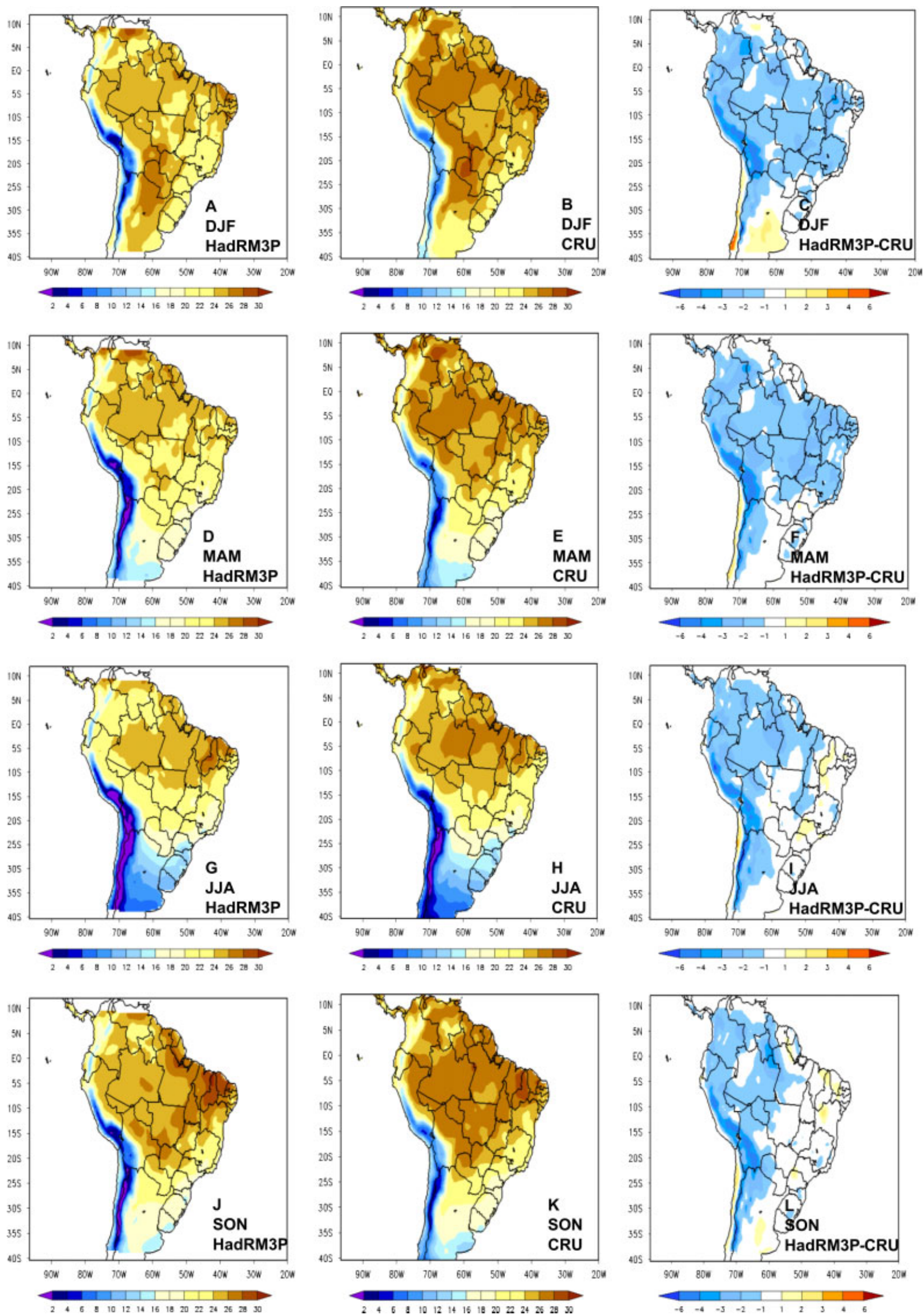

Figure 2. Present climate seasonal air temperature $\left({ }^{\circ} \mathrm{C}\right)$ simulated by the HadRM3P regional model (left), and from observations [CRU-center: $(\mathrm{a}-\mathrm{c})$ Summer (DJF); (d-f) Autumn (MAM); (g-i) Winter (JJA); (j-l) Spring (SON). Bias (difference between model and observations) is shown to the extreme right. This figure is available in colour online at www.interscience.wiley.com/ijoc 

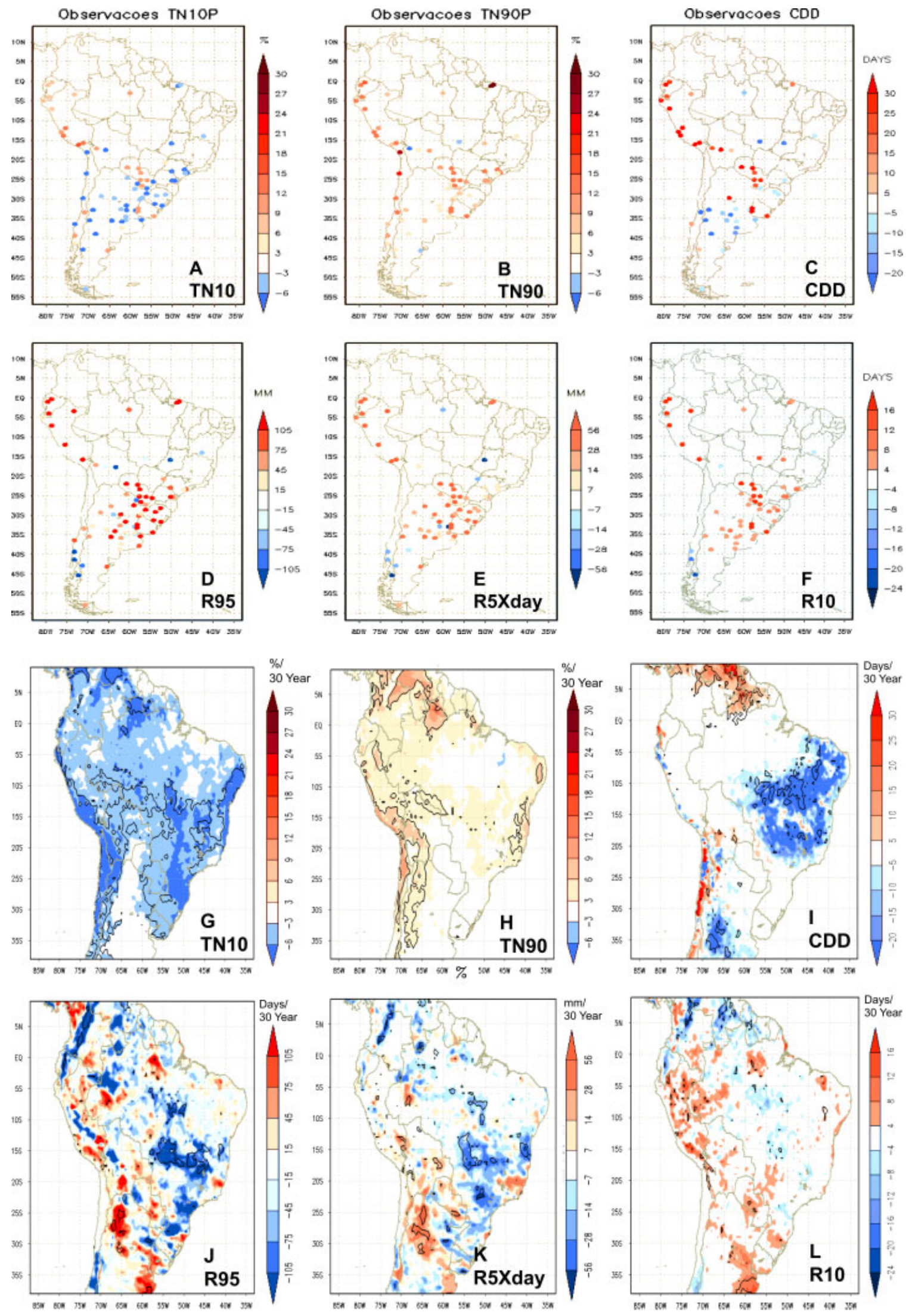

Figure 3. Observed and simulated trends of extreme climate indices for 1961-1990. The trend is assumed as linear and represents the values of 1990 minus 1961. (a-f) represent observations and ( $\mathrm{g}-\mathrm{l}$ ) represent HadRM3 (PRECIS) simulations. (a, g) TN10 in percentage/30 years; (b, h) TN90 in percentage/30 years; (c, i) CDD in days/30 years; (d, j) R95P in millimetre/30 years; (e, k) R $\times 5$ Days in millimetre/30 years; (f, 1 ) $\mathrm{R} 10$ days/30 years. Colour scale is shown on the lower side of the simulated indices maps. Black line delimitates areas where the linear trend is statistically significant at 5\% level using the Student's t-test. This figure is available in colour online at www.interscience.wiley.com/ijoc 

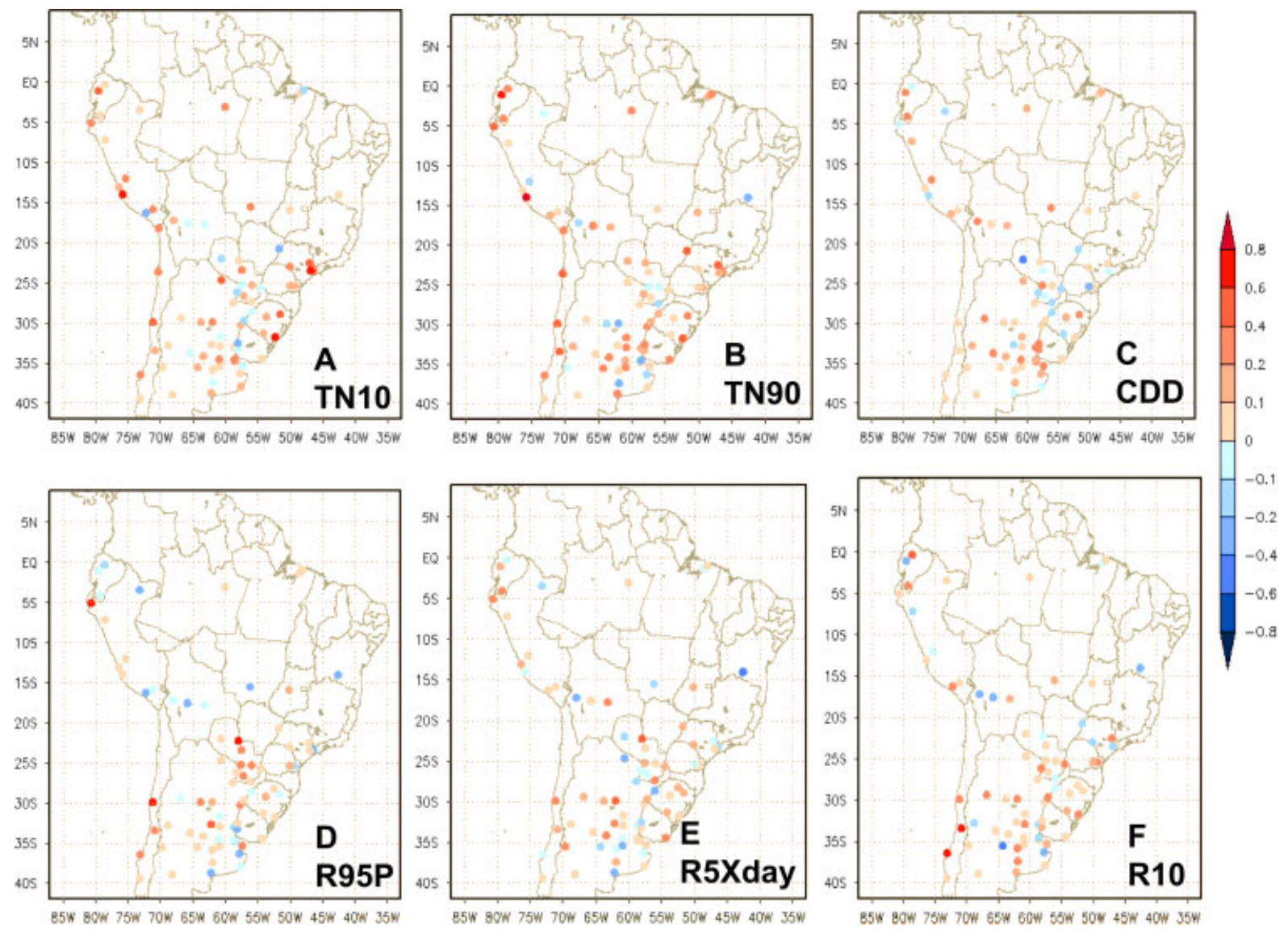

Figure 4. Correlation coefficients between model ensemble mean anomalies and observed anomalies of rainfall: (a) DJF, (b) MAM, (c) JJA and (d) SON. Colour scale shows the values of the correlations. Values above 0.45 reach statistically significance at the $95 \%$ level $5 \%$. This figure is available in colour online at www.interscience.wiley.com/ijoc

inconsistent with those two stations between $15^{\circ}$ and $20^{\circ} \mathrm{S}$. The simulated positive rainfall extreme trends in Northeastern Brazil, and in southern Brazil-northern Argentina are also detected in the observational studies on rainfall extremes by Groissman et al. (2005) and Rusticucci and Barrucand (2004), respectively. Over Chile again negative trends observed are captured by the HadRM3P simulations.

The CDD maps show that the model reproduces well the negative trends in central Argentina and west central Brazil south of $15^{\circ} \mathrm{S}$, and in the model the negative trends extend to Northeast Brazil. The observations show positive trends in Uruguay and in the boundary region between Argentina-Paraguay-Brazil while the model does not show any trend. Extreme northern Amazonia and Venezuela show positive trends in simulated CDD that are consistent with positive CDD trends observed in that region by Alexander et al. (2006).

In a qualitative comparison of present day extreme indices simulated by the CMIP3 GCMs for the twentieth century from Tebaldi et al. (2006) and simulations with HadRM3P, perhaps the best agreement is found for TN90 and the worst for CDD. The R10 simulations show similar distributions between the patterns from both AGCMs and regional simulations, with positive trends in Southeastern Brazil and Western Amazonia and negative trends in northern South America and southern Chile.
To quantify this comparison of observed and simulated trends for the six extreme indices we determine the extent to which trends in station data and data from the RCM grid-box containing the station are correlated. This provides quantitative evidence to support the description of the trend analysis and highlight differences in between model and observations show in Figure 3. There is a better agreement between changes in extremes and the modeled and observed trends for temperature-based indices and compared to rainfall based indices. Figure 4 $(a-f)$ shows higher correlations between observed and modeled fields for the temperature-based indices, where positive correlations are detected in about $90 \%$ of the total of stations, with higher values in Western and Southeastern South America. This suggests that the RCM simulates well the observed warming as expressed by the indices derived from maximum and minimum temperatures.

For the rainfall based indices in Figure 4, the correlations are not as high as those from TN10 or TN90, but are still positive in about $80 \%$ of the stations. At the regional level, in Southeastern South America and southern Brazil correlations are positive. In some stations of Bolivia, parts of Paraguay and in the Brazilian state of Bahia the correlations are negative in all temperature and rainfall and temperature-based indices. This may indicate a model deficiency or be due to a missing process such 
as land-use change or urbanization or result from quality control problems with the observed data. However, consistency in more than $80 \%$ of the stations shows a robust pattern of agreement, which is unlikely to be due to chance.

\section{HadRM3P derived future changes in extremes}

Before discussing the particular features of the downscaling for extremes in the future, we discuss the mean climatic features of climate change projections for both A2 and B2 scenarios for 2071-2100 produced by the HadRM3P model. These projections were derived from the downscaling of the HadAM3P global model as documented in Ambrizzi et al. (2007) and Marengo et al. (2007). In the Amazon region, the projection for the B2 scenario is that air temperatures may increase between 3 and $4{ }^{\circ} \mathrm{C}$ and rainfall may reduce by $5-20 \%$ in eastern Amazonia compared to the recent past. In Northeast Brazil these changes can vary from 1 to $4{ }^{\circ} \mathrm{C}$ of warming with rainfall reductions of between 10 and $15 \%$. The projection under the A2 is for even larger changes (reaching up to $8{ }^{\circ} \mathrm{C}$ and $40 \%$ drier in both Eastern Amazonia and Northeast Brazil). Small increases of rainfall in southern Brazil and northern Argentina of up to 5-10\% are projected under the A2 and B2 scenarios.

The large-scale long-term warming in the SSTs driving the HaAM3P future simulation has, in the tropical Pacific, a pattern typical of a strong El Nino. As with a strong El Nino, this increases subsidence over tropical South America east of the Andes and thus reduces rainfall and increases convection in the Northwest coast of Peru-Ecuador and in northern Argentina. This also implies changes in the low level moisture transport east of the Andes (the South American Low Level Jet or SALLJ), which brings moisture from the Amazon to the southern Brazil-northern Argentina region, and according to ongoing studies this transport may increase in frequency and intensity in future warm climates. Also, the tropical drying and heating trend may be reinforced by the large-scale 'die-back' of eastern Amazon rainforests as they are replaced by savanna-like and semi-arid vegetation, as suggested by Cox et al. (2000) and Oyama and Nobre (2003) using the HadCM3 and the CPTEC global models, respectively, though these vegetation interactions are not simulated in the experiments reported in this paper.

In general the temperature-based indicator changes [Figure $5(\mathrm{a}, \mathrm{b}, \mathrm{g}$, and $\mathrm{h})$ ] are consistent with the expected warmer future climate, with negative trends in cold nights and positive trends in warm nights. The trends are larger for A2 especially in tropical South America and the Andean regions while the trends are smaller of $20^{\circ} \mathrm{S}$. Under the B2 scenario there are no significant changes in warm nights of $20^{\circ} \mathrm{S}$ and in some eastern tropical areas and even for a small area in Argentina under the A2 scenario. These projected trends seem to be a continuation of the generally negative and positive observed trends. The projected positive trends in TN90 from the PRECIS simulations are also consistent with the positive and statistically significant TN90 trends detected in the CMIPs global multi-model simulation, especially in the region extending from Bolivia to central Brazil in the A1B scenario from Tebaldi et al. (2006).

An expected consequence of global warming is an intensification of the hydrological cycle. In very broad terms this would be expected to increase the frequency and intensity of extreme rainfall events and also dry spells (Intergovernmental Panel on Climate Change IPCC, 2007a, 2007b) though significant regional and local deviations from this picture are likely (Christensen et al., 2007a). In the climate response to global warming projected by PRECIS the changes in occurrence of R95P, $\mathrm{R} \times 5$ day and R10mm (Figure 5 [d, e, j, k)] suggest increases in the frequency and intensity of extreme rainfall events in western Amazonia, the northern coast of Peru and Ecuador and in southeastern South America. The patterns are similar for the two emissions scenarios and in the A2 changes are larger in western Amazonia and southern Brazil. Negative trends are projected for northern South America and the eastern Amazonia-Northeast Brazil region, and again are larger in the A2 scenario.

The projected trends in Southeastern South America show basically a continuation and intensification of the positive rainfall extreme trends detected during the second half of the twentieth century. These future trends, according to recent study by Soares and Marengo (2008) are consistent with a tendency of intensification of the SALLJ (more frequent and more intense) in both the IPCC A2 and B2 scenarios. They found an intensification of the moisture flux between the Amazonia and the La Plata Basin, where larger amounts of moisture circulate faster from the tropics to mean latitude by an intensified and more frequent SALLJ, and thus more moisture would be available at the exit region of the jet for the development of storms and more frequent and intense extreme rainfall events.

On the other hand, the CDD index shows an increasing trend in the region extending from eastern Amazonia to Northeast Brazil which is inconsistent with the model trend in the control simulations (and the few stations with available data consistent with this). In the A2 scenario this extends into the northern South American coast (which is consistent with the model control trends) and into southeastern Brazil in the A2 scenario until the end of the twenty-first century. Significant trends are also projected under the A2 scenario for Bolivia.

In the context of trends in extremes, the results here imply that the projected rainfall reduction in eastern Amazonia and Northeast Brazil in the future would be seen through an increase in positive CDD trends under both emission scenarios, accompanied by reductions in heavy precipitation events.

The observed extreme rainfall trends in Southeastern South America, some of which are also simulated by the HadRM3P control run, are very relevant. Extreme rainfall events have affected large cities such as Sao Paulo, Rio 

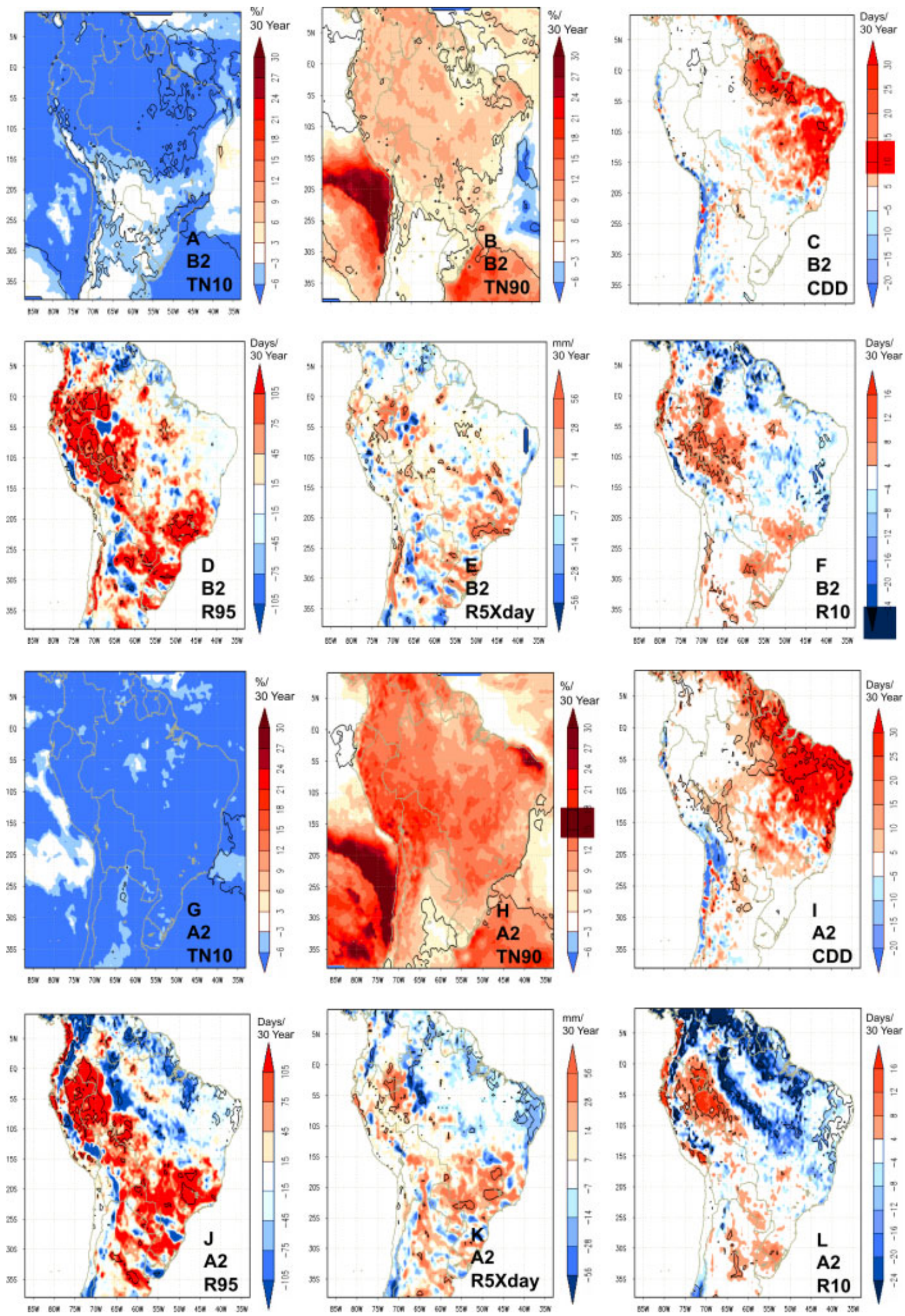

Figure 5. Projected trends of extreme climate indices for 2071-2100 relative do 1961-1990. (a-f) projections for the B2 scenario, and (g-1) show projections for the A2 scenario. (a, g) TN10 in percentage/30 years; (b, h) TN90 in percentage/30 years; (c, i) CDD in days/30 years; (d, j) R95P in millimetre/30 years; (e, k) $\mathrm{R} \times 5$ Days in millimetre/30 years; (f, l) R10 days/30 years. Colour scale is shown on the lower side of each panel, and the black line delimitates areas where the linear trend is statistically significant at $5 \%$ level using the Student's t-test. This figure is available in colour online at www.interscience.wiley.com/ijoc 
de Janeiro and Buenos Aires resulting in an increase in flooding events during the last 50 years (Marengo et al., 2007). If these changes continue in the future as projected here by PRECIS then this would results in huge economic losses due to increased risk of floods. These results also imply that the positive rainfall trends in southern Brazil and northern Argentina projected by the HadRM3P model would be due an increase in the frequency of some intense rainfall in the future. The most marked increases in extreme rainfall are projected for western Amazonia implying higher flood risk here. As demonstrated above, these changes will be seen in part through a range of different changes in extremes and a full description of all these changes are required to provide a comprehensive assessment of their impact. Therefore, there is consistency between observed and projected changes in this and several studies and the spatial agreement between significant regional warming.

As it was shown in PRUDENCE, the largest source of uncertainty in the regional simulations was the choice of global model. The CMIP3 models have shown little coherence over tropical South America (Christensen et al., 2007a), and future responses in precipitation, particularly over tropical South America, vary widely. We acknowledge that if the purpose is to provide information on extremes for impact studies, then the use of a single global model for downscaling is wholly inadequate. The rationale for the choice of global model HadAM3P was because of: (1) the model seems to reproduce quite well seasonal distribution and variability of rainfall over large areas of South America despite some systematic errors, (2) it was, at the time, the only global model available with the time resolution (every $6 \mathrm{~h})$ for dynamic downscaling experiments, and (b) its has been investigated quite thoroughly in various regions of the globe in previous downscaling experiences, as in PRUDENCE, NAARCAP and the various PRECIS applications noted in the introduction.

\section{Conclusions}

Simulations using the Hadley Centre's regional climate modeling system PRECIS of South American climate of the recent past and two possible future climates have been analysed to provide guidance on how climate extremes may change over the region. Validation of the simulated climate of 1961-1990 shows that the pattern of temperature extremes is similar between model and observations in Southeastern South America. Cold and warm nights validate well except for the former over Paraguay and the northern Peru/Ecuador region. Possibly linked to this are strong observed trends in these regions in the maximum dry spell length which the model also does not simulate. The lack of rainfall implied by increased dry spell length will probably be associated with reduced cloudiness leading to increased longwave cooling at nights and thus more cold nights. Maximum dry day trends in other regions (mostly negative) are simulated by the HadRM3P as most of the heavy and extreme precipitation trends are analysed. The validation reported here is far from comprehensive due to the small number of stations available which in particular results in an almost complete lack of reliable information in tropical South America.

Changes in these extreme indices were analysed for projections of the climate of 2071-2100 under the IPCC SRES A2 and B2 emissions scenarios. Cold and warm night trends are, respectively, negative and positive as expected with the response larger in tropical regions and under the A2 scenario. South of $20^{\circ} \mathrm{S}$ and in some eastern tropical areas there are no significant changes projected under the B2 emissions scenario. Tropical warm night trends are consistent with analyses of the multi-model ensemble assessed in the IPCC AR4.

Projected changes in the precipitation indices are more complex. Changes in annual rainfall resulting from the top $5 \%$ of daily precipitation events, the maximum 5 day rainfall total and the number of days with heavy precipitation (greater than $10 \mathrm{~mm}$ ) all show increases in western Amazonia, the northern coast of Peru and Ecuador and in southeastern South America. Negative trends are projected for northern South America and the eastern Amazonia-Northeast Brazil region. All these trends are larger under the A2 scenario. The projected trends in Southeastern South America continue and intensify those observed during the second half of the twentieth century. Projected dry spell length increases over eastern Amazonia-Northeast Brazil and Bolivia are only significant in some areas (which are larger under the A2 emissions). Only the Bolivian changes are consistent with those observed.

A major objective of analysing HadRM3P simulations of extreme climate events under past and possible future emissions is to provide projections of future regional extreme climate events that could be used in impact studies in South American countries. For example, the projected increases in extreme rainfall for western Amazonia (the clearest hydrological cycle signal analysed) imply increased flood risk there. Similar changes over southeastern regions also imply significant increases in economic losses in the major cities there. Over eastern Amazonia the projected changes in dry spell length and the associated changes in average rainfall would lead to significant changes in the natural vegetation and thus impacts on ecosystems and biodiversity. Climate change is expected to modify the frequency, intensity and duration of extreme events in many regions (Christensen et al., 2007a). It is impossible to attribute single extreme events directly to anthropogenic climate change because of the probabilistic nature of these events. There is always a chance that any given event may be a result of natural climate variability, even if an event of such magnitude has never been recorded. Therefore, it is necessary to use models to augment observations in attempting to understand the changing likelihood of extremes under climate change scenarios, e.g. through calculating the enhanced risk of an extreme attributable to climate change as in 
Stott et al. (2004) for the heat wave in Europe in summer of 2003. If models can be shown to simulate the observed variability of extremes, then they can be used with a degree of confidence to provide reliable estimates of extremes within a given climate change scenario.

Future work will include the use of other regional models for downscaling a more comprehensive set of HadCM3-based future scenarios and also we plan to use other global models. It is clear that a dynamic downscaling experiment would have greater value if using boundary conditions from more than one global model, with the value further improved if additional emissions scenarios are contemplated. Currently INPE is working on dynamically downscaling experiments from a perturbed physics ensemble of GCMs based on HadCM3 (Collins et al., 2006) and ECHAM4 using the Eta model at $40 \mathrm{~km}$ resolution for 1960-2100, and not just 2071-2100 as in the PRECIS type experiments. Analysis of these experiments will focus on providing estimates of likely ranges of future climate changes.

Another crucial area of future work is to improve access to data from and increase the observational network in tropical South America so the model can be validated for these regions. The limitations of the observational network are clearly evidenced in Figure 1. Large areas of tropical South America do not show comprehensive, homogeneous and high quality data. Currently, some meteorological services in South America are performing a major task of digitalizing and checking climate series that are currently on paper form and tapes. New initiatives are being proposed to build a consolidate hydrometeorological data bank in Amazon countries, organized by the Amazon Cooperation Treaty, and in Southern South America as part of the CLARIS-EU project. The idea is to provide high quality data for South America for trend analyses that would be useful for the computation of indices of extremes, as those defined by Frisch et al. (2002) and new ones that are being implemented by IPCC for the Fifth Assessment Report. This well help in understanding the reasons for observed changes in climate extremes and in improving confidence in projected changes.

\section{Acknowledgements}

We would like to thank the Hadley Centre for providing the PRECIS model system. CREAS is funded by MMA/BIRD/GEF/CNPq (PROBIO Project), the Brazilian National Climate Change Program from the Ministry of Science and Technology MCT, the UK Global Opportunity Fund-GOF Project Using Regional Climate Change Scenarios for Studies on Vulnerability and Adaptation in Brazil and South America, and GOFDangerous Climate Change (DCC), the GEOMA and the LBA2 Millennium Institute and the CLARIS-EU project. Richard Jones was supported by the Joint Defra and MoD Programme, (Defra) GA01101 (MoD) CBC/2B/0417_Annex C5.

\section{References}

Alexander LV, Zhang X, Peterson TC, Caesar J, Gleason B, Klein Tank A, Haylock M, Collins D, Trewin B, Rahimzadeh F, Tagipour A, Ambenje P, Rupa Kumar K, Revadekar J, Griffiths G, Vincent L, Stephenson D, Burn J, Aguilar E, Brunet M, Taylor M, New M, Zhai P, Rusticucci M, Vazquez-Aguirre JL. 2006. Global observed changes in daily climate extremes of temperature and precipitation. Journal of Geophysical Research 111: D05109, DOI:10.1029/2005JD006290.

Alves L. 2007. Simulações da Variabilidade do Clima Presente sobre a América do Sul utilizando um Modelo climático Regional. M.S. Dissertation. Instituto Nacional de Pesquisas Espaciais, INPE, São Jose dos Campos, São Paulo, Brazil; 230.

Ambrizzi T, Rocha R, Marengo JA, Pisnitchenko I, Alves L. 2007. Cenários Regionalizados de Clima no Brasil para o Século XXI: Projeções de clima usando três modelos regionais. Relatório 3, MINISTÉRIO DO MEIO AMBIENTE - MMA, SECRETARIA DE BIODIVERSIDADE E FLORESTAS - SBF， DIRETORIA DE CONSERVAÇÃO DA BIODIVERSIDADE - DCBio Mudanças Climáticas Globais e Efeitos sobre a Biodiversidade - Sub projeto: Caracterização do clima atual e definição das alterações climáticas para o território brasileiro ao longo do Século XXI. Brasília, Fevereiro, 2007.

Caesar J, Alexander L, Vose R. 2006. Large-scale changes in observed daily maximum and minimum temperatures: creation and analysis of a new gridded data set. Journal of Geophysical Research 111: D05101, DOI:10.1029/2005JD006280.

Christensen JH, Christensen OB. 2003. Climate modeling: severe summertime flooding in Europe. Nature 421: 805-806.

Christensen JH, Hewitson B, Busuioc A, Chen A, Gao X, Held I, Jones R, Kolli RK, Kwon W-T, Laprise R, Magaña Rueda V, Mearns L, Menéndez CG, Räisänen J, Rinke A, Sarr A, Whetton P. 2007a. Regional climate projections. In: Chapter 11, Contribution of Working Group I to the Fourth Assessment Report of the Intergovernmental Panel on Climate Change Climate Change 2007:The Physical Science Basis, Solomon S, Qin D, Manning M, Chen Z, Marquis M, Averyt KB, Tignor M, Miller HL (eds). Cambridge University Press: Cambridge, United Kingdom and New York, NY.

Christensen JH, Carter TR, Rummukainen M, Amanatidis G. 2007b. Evaluating the Performance and Utility of Regional Climate Models: the PRUDENCE Project. Climatic Change 81: 1-6, DOI:10.1007/s10584-006-9211-6.

Chou SC, Bustamante JF, Gomes JL. 2004. Previsões sazonais utilizando o modelo Eta/CPTEC sobre América do Sul. Proceedings of XIII Congress Bras de Meteorologia, Fortaleza, Brasil, (in CDROM).

Chou SC, Tanajura CA, Xue Y, Nobre CA. 2002. Validation of the coupled Eta/CPTEC/SSiB model over South America. Journal of Geophysical Research 107(D20): 34, 37, DOI:10.1029/ 2000JD000270.

Collins M, Booth BBB, Harris GR, Murphy JM, Sexton DMH, Webb MJ. 2006. Towards quantifying uncertainty in transient climate change. Climate Dynamics 27: 127-147, DOI:10.1007/s00382-0060121-0.

Cox P, Betts R, Jones C, Spall S, Totterdell T. 2000. Acceleration of global; warming due to carbon-cycle feedbacks in a coupled climate model. Nature 408: 184-187.

Dessai S, Lu X, Risbey JS. 2005. On the role of climate scenarios for adaptation planning. Global Environmental Change 15: 87-97.

Frei C, Scholl R, Fukutome S, Schmidli J, Vidal PL. 2006. Future change of precipitation extremes in Europe: intercomparison of scenarios from regional climate models. Journal of Geophysical Research 111: D06105, DOI:10.1029/2005JD005965.

Frich P, Alexander LV, Della-Marta P, Gleason B, Haylock M, Klein Tank AMG, Peterson T. 2002. Observed coherent changes in climatic extremes during the second half of the twentieth century. Climate Research 19: 193-212.

Gao X, Pal JS, Giorgi F. 2006. Projected changes in mean and extreme precipitation over the Mediterranean region from a high resolution double nested RCM simulation. Geophysical Research Letters 33: L03706, DOI:10.1029/2005GL024954.

Giorgi F, Bi X, Pal JS. 2004. Mean, interannual variability and trends in a regional climate change experiment over Europe. I: present day climate (1961-1990). Climate Dynamics 22: 7333-7756.

Giorgi F, Hewitson B, Christensen J, Hulme M, Von Storch H, Whetton P, Jones R, Mearns L, Fu C. 2001. Regional climate 
information: evaluation and projections (Chapter 10). In: Climate Change 2001: The Scientific Basis, Contribution of Working Group I to the Third Assessment Report of the IPCC, Houghton JT, Ding Y, Griggs DJ, Noguer M, van der Linden PJ, Dai X, Maskell K, Johnson CA (eds). Cambridge University Press: Cambridge; 739-768.

Gordon C, Cooper C, Senior CA, Banks H, Gregory JM, Johns TC, Mitchell JFB, Wood RA. 2000. The simulation of SST, sea ice extent and ocean heat transports in a version of the Hadley Centre coupled model without flux adjustments. Climate Dynamics 16: 147-168.

Groissman P, Knight P, Easterling D, Karl T, Hegerl G, Razuvaek V. 2005. Trends in intense precipitation in the climate record. Journal of Climate 18: $1326-1350$.

Haylock MR, Peterson T, Abreu de Sousa JR, Alves LM, Ambrizzi T, Baez J, Barbosa de Brito JI, Barros VR, Berlato MA, Bidegain M, Coronel G, Corradi V, Garcia VJ, Grimm AM, Jaildo dos Anjos R, Karoly D, Marengo JA, Marino MB, Meira PR, Miranda GC, Molion L, Muncunil DF, Nechet D, Ontaneda G, Quintana J, Ramirez E, Rebello E, Rusticucci M, Santos JL, Varillas IT, Vincent L, Yumiko M. 2006. Trends in total and extreme South American rainfall 1960-2000 and links with sea surface temperature. Journal of Climate 19: 1490-1512.

Hegerl GC, Zwiers FW, Stott PA, Kharin VV. 2004. Detectability of anthropogenic changes in temperature and precipitation extremes. Journal of Climate 17: 3683-3700.

Hewitt CD, Griggs DJ. 2004. Ensembles-based predictions of climate changes and their impacts. EOS Transactions AGU 85(52): 566, DOI:10.1029/2004EO520005.

Hulme M, Jenkins GJ, Lu X, Turnpenny JR, Mitchell TD, Jones RG, Lowe J, Murphy JM, Hassell D, Boorman P, Macdonald R, Hill S. 2002. Climate-Change Scenarios for the United Kingdom: The UKCIP02 Scientific Report. Tyndall Centre for Climate Change Research. School of Environmental Sciences. University of East Anglia: Norwich, UK: 120.

Intergovernmental Panel on Climate Change IPCC. 2007a. Climate Change 2007: The Physical Science Basis Summary for Policymakers Contribution of Working Group I to the Fourth Assessment Report of the Intergovernmental Panel on Climate Change. 18.

Intergovernmental Panel on Climate Change IPCC. 2007b. Working Group II Contribution to the Intergovernmental Panel on Climate Change Fourth Assessment Report Climate Change 2007: Climate Change Impacts, Adaptation and Vulnerability. Summary for Policymakers, 23.

Islam S and Rehman N. 2006. Future change in the frequency of warm and cold spells durations over Pakistan simulated by the PRECIS regional climate model. Paper presented in the Second International Young Scientists' Global Change Conference, Beijing, 7-9 November 2006, organised by START (the global change SysTem for Analysis, Research and Training) and the China Meteorological Administration. Available from:http://precis.metoffice.com/docs/poster-china-final_siraj.pdf

Jones RG, Murphy JM, Noguer M. 1995. Simulation of climate change over Europe using a nested regionalclimate model. 1: assessment of control climate, including sensitivity to location of lateral boundaries. Quarterly Journal of the Royal Meteorological Society 121: $1413-1449$.

Jones RG, Murphy JM, Hassell DC, Woodage MJ. 2008. A high resolution atmospheric GCM for the generation of regional climate scenarios. Climate Dynamics Submitted.

Jones RG, Noguer M, Hassell D, Hudson D, Wilson S, Jenkins G, Mitchell J. 2004. Generating High Resolution Climate Change Scenarios using PRECIS, report, Met Office Hadley Centre: Exeter, UK.

Kendon EJ, Rowell DP, Jones RG, Buonomo E. 2008. Robustness of future changes in local precipitation extremes. Journal of Climate DOI:10.1175/2008JCLI2082.1.

Kiktev D, Sexton DMH, Alexander L, Folland CK. 2003. Comparison of modeled and observed trends in indices of daily climate extremes. Journal of Climate 16: 3560-3571.

Li W, Fu R, Dickinson RE. 2006. Rainfall and its seasonality over the Amazon in the 21st century as assessed by the coupled models for the IPCC AR4. Journal of Geophysical Research 111: D02111, DOI:10.1029/2005JD006355.

Marengo JA, Alves L, Valverde M, Rocha R, Laborbe R. 2007. Eventos Extremos em Cenários Regionalizados de Clima no Brasil e América do Sul para o Século XXI: Projeç̃es de Clima Futuro Usando três Modelos Regionais. Relatório 5, Ministério do Meio Ambiente - MMA, Secretaria de Biodiversidade e Florestas - SBF,
Diretoria de Conservação da Biodiversidade - DCBio Mudanças Climáticas Globais e Efeitos sobre a Biodiversidade - Sub projeto: Caracterização do clima atual e definição das alterações climáticas para o território brasileiro ao longo do Século XXI. Brasília Fevereiro, 2007

Marengo J, Ambrizzi T. 2006. Use of regional climate models in impacts assessments and adaptations studies from continental to regional and local scales: The CREAS (Regional Climate Change Scenarios for South America) initiative in South America. Proceedings of 8 ICSHMO, Foz do Iguaçu, Brazil, April 24-28, 2006, 291-296.

Marengo J, Camargo CC. 2007. Surface air temperature trends in Southern Brazil for 1960-2002. International Journal of Climatology 28: 893-904, DOI:10.1002/joc.1584.

Marengo JA, Cavalcanti IFA, Satyamurty P, Trosnikov I, Nobre CA, Bonatti JP, Camargo H, Sampaio G, Sanches MB, Manzi AO, Castro CAC, D'Almeida C, Pezzi LP, Candido L. 2003. Assessment of regional seasonal rainfall predictability using the CPTEC/COLA atmospheric GCM. Climate Dynamics 2003 21: 459-475, DOI 10.1007/s00382-003-0346-0.

Mearns L. 2004. NARCCAP North American regional climate change assessment program A multiple AOGCM and RCM climate scenario project over North America. AGU Fall Meeting. 12/17/2004. San Francisco.

Mearns LO, Hulme M, Carter TR, Leemans R, Lal M, Whetton P. 2001. Climate scenario development (Chapter 13). In: Climate Change 2001: The Scientific Basis, Contribution of Working Group I to the Third Assessment Report of the IPCC, Houghton JT, Ding Y, Griggs DJ, Noguer M, van der Linden PJ, Dai X, Maskell K, Johnson CA (eds). Cambridge University Press: Cambridge; 583-638.

Meehl G, Covey C, Delworth T, Latif M, McAvaney B, Mitchell JFB, Stouffer RJ, Taylor KE. 2007. The WCRP CMIP3 Multimodel data set. A new era in climate change research. Bulletin of the American Meteorological Society 1383-1394, DOI:10.1175/BAMS88-9-1383.

Misra V, Dirmeyer PA, Kirtman BP. 2003. Dynamic downscaling of seasonal simulation over South American. Journal of Climate 16: $103-117$.

Morales P, Hickler T, Rowell DP, Smith B, Sykes MT. 2007. Changes in European ecosystem productivity and carbon balance driven by regional climate model output. Global Change Biology 13: 108-122, DOI:10.1111/j.1365-2486.2006.01289.

Nakicenovic N, Alcamo J, Davis G, de Vries B, Fenhann J, Gaffin S, Gregory K, Grubler A, Jung TY, Kram T, La Rovere EL, Michaelis L, Mori S, Morita T, Pepper W, Pitcher H, Price L, Riahi K, Roehrl A, Rogner H-H, Sankovski A, Schlesinger M, Shukla P, Smith S, Swart R, van Rooijen S, Victor N, Dadi Z. 2000. Special Report on Emissions Scenarios Cambridge 599.

New M, Todd M, Hulme M, Jones P. 2001. Precipitation measurements and trends in the twentieth century. International Journal of Climatology 21: 1899-1922.

Nicolini M, Salio P, Katzfey JJ, McGregor JL, Saulo AC. 2002. January and July regional climate simulation over South American. Journal of Geophysical Research 107(D22): 4637.

Nuñez M, Solman S, Cabré MF. 2006. Mean climate and annual cycle in a regional climate change experiment over Southern South America. II: Climate change scenarios (2081-2090), Proceedings of 8 ICSHMO, April 24-28, 2006, Foz do Iguaçu, Brazil; 325-331.

Oyama MD, Nobre CA. 2003. A new climate-vegetation equilibrium state for Tropical South America. Geophysical Research Letters 30(23): 2199, DOI:10.1029/2003GL018600.

Pisnichenko IA, Tarasova TA. 2007. The climate version of the Eta regional forecast model.1. Evaluation of consistency between the Eta model and HadAM3P global model, http://arxiv.org/abs/0709.2110v2.

Pope VD, Gallani ML, Rowntree PR, Stratton RA. 1999. The impact of new physical parametrizations in the Hadley Centre climate model: HadAM3. Climate Dynamics 16: 123-146.

Rowell DP. 2005. A scenario of European climate change for the late twenty-first century: Seasonal means and interannual variability. Climate Dynamics 25: 837-849, DOI:10.1007/s00382-005-0068-6.

Rowell DP, Zwiers FW. 1999. The global distribution of sources of atmospheric decadal variability and mechanisms over the tropical Pacific and southern North America. Climate Dynamics 15: $751-772$. 
Rupa Kumar K, Sahai AK, Krishna Kumar K, Patwardhan SK, Mishra PK, Revadekar JV, Kamala K, Pant GB. 2006. Highresolution climate change scenarios for India for the $21^{\text {st }}$ century. Current Science 90: 334-345.

Rusticucci M, Barrucand M. 2004. Observed trends and changes in temperature extremes in Argentina. Journal of Climate 17: 4099-4107.

Seluchi ME, Chou SC. 2001. Evaluation of two Eta/CPTEC Model versions for weather forecast over South America. Geofisica Internacional 40: 219-237.

Seth A, Rojas M. 2003. Simulation and sensitibity in a nested modeling system for South America. Part I: reanalysis boundary forcing. Journal of Climate 16: 2437-2453.

Soares W, Marengo JA. 2008. Assessments of moisture fluxes east of the Andes in South America in a global warming scenario. DOI: 10.1002/joc. 1800 .

Solman S, Nuñez M, Cabre MF. 2008. Regional climate change experiments over southern South America. I: present climate. Climate Dynamics 30: 533-552, DOI:10.1007/s00382-0070304-3.

Stott PA, Stone DA, Allen MR. 2004. Human contribution to the European heatwave of 2003. Nature 432: 610-614.

Tadross M, Jack C, Hewitson B. 2005. On RCM-based projections of change in southern African summer climate. Geophysical Research Letters 32: L23713, DOI:10.1029/2005GL024460.

Tebaldi C, Hayhoe K, Arblaster J, Meehl G. 2006. Going to the extremes: an intercomparison of model-simulated historical and future changes in extreme events. Climatic Change 79: 185-211, DOI:10.1007/s10584-006-9051-4.
Vera C, Silvestri G, Liebmann B, González P. 2006. Climate change scenarios for seasonal precipitation in South America from IPCC-AR4 models. Geophysical Research Letters 33: L13707, DOI:10.1029/2006GL025759.

Vincent LA, Peterson TC, Barros VR, Marino MB, Rusticucci M, Carrasco G, Ramirez E, Alves LM, Ambrizzi T, Berlato MA, Grimm AM, Marengo JA, Molion L, Moncunill DF, Rebello E, Anunciação YMT, Quintana J, Santos JL, Baez J, Coronel G, Garcia J, Trebejo I, Bidegain M, Haylock MR, Karoly D. 2005. Observed trends in indices of daily temperature extremes in South America 1960-2000. Journal of Climate 18: 5011-5023.

Washington R, Harrison M, Conway D, Black E, Challinor A, Grimes D, Jones R, Morse A, Kay G, Todd M. 2006. African climate change: taking the shorter route. Bulletin of the American Meteorological Society 87: 1355-1366.

Wilby RL, Wigley TML. 1997. Downscaling general circulation model output: a review of methods and limitations. Progress in Physical Geography 21: 530-548.

Xu YL, Huang XY, Zhang Y, Lin WT, Lin ED. 2006a. Statistical analyses of climate change scenarios over China in the $21^{\text {st }}$ century. Advances in Climate Change Research 2(Suppl. 1): 50-53.

Xu YL, Zhang Y, Lin ED, Lin WT, Dong WJ, Jones R, Hassell D, Wilson S. 2006b. Analyses on the climate change responses over China under SRES B2 scenario using PRECIS. Chinese Science Bulletin 51(18): 2260-2267.

Zhang Y, Yinlong X, Wenjie D, Lijuan C, Sparrow M. 2006. A future climate scenario of regional changes in extreme climate events over China using the PRECIS climate model. Geophysical Research Letters 33: L24702, DOI:10.1029/2006GL027229. 